\title{
Comparison of prolene and progrip meshes in inguinal hernia repair in terms of post-operative pain, limitation of movement and quality of life
}

\author{
Ahmet Kaya ${ }^{1}($ ID), Semra Tutcu Şahin²(ID), Yavuz Kaya²(ID), Teoman Coşkun²(ID), Aslan Sakarya²(ID) \\ ${ }^{1}$ Division of Surgical Oncology, Sakarya University School of Medicine, Sakarya, Turkey \\ 2 Department of General Surgery, Celal Bayar University School of Medicine, Manisa, Turkey
}

\begin{abstract}
Objective: The study aimed to compare the techniques applying prolene mesh and progrip-self fixating mesh in terms of post-operative pain, limitation of movement and quality of life.

Material and Methods: The study was conducted from November 2014 to January 2016 in Department of Surgery, Manisa Celal Bayar University Hospital. The study recruited 50 male patients, aged 18 and over and was carried out as a double blinded procedure. Twenty-five patients were randomly selected to receive hernia repair by progrip self-fixating mesh and 25 patients were treated with hernia repair with suture fixation method by using prolene grafts, and patients' pain follow-up was performed with face-to-face or telephone interviews with VAS (Visual Analogue Scale) and return to daily routine activities were evaluated with SF-36 (Short Form-36) quality of life scale. Recurrent hernias and emergency cases were excluded.

Results: The pain scores were lower and a statistically significant difference was achieved in patients in whom progrip self-fixating mesh was used in the early postoperative period. Both methods gave statistically similar results in terms of pain and quality of life.

Conclusion: In the literature, there are some evidence that the repair applied with progrip self-fixating graft has more positive outcomes compared to the repairs applied with suture fixation. It is concluded that there is a need for longer follow-ups and larger series of cases in order to achieve a definite result.
\end{abstract}

Keywords: Inguinal hernia, pain, progrip mesh, prolene mesh, quality of life

Cite this article as: Kaya A, Tutcu Şahin S, Kaya Y, Coşkun T, Sakarya A. Comparison of prolene and progrip meshes in inguinal hernia repair in terms of post-operative pain, limitation of movement and quality of life. Turk J Surg 2020 $36(1): 48-52$

\section{Corresponding Author}

Ahmet Kaya

E-mail: ahmet.kaya@cbu.edu.tr

Received: 11.03 .2019

Accepted: 06.11.2019

Available Online Date: 18.03 .2020

( Copyright 2020 by Turkish Surgical Society Available online at www.turkjsurg.com

DOI: $10.5578 /$ turkjsurg.4451

\section{INTRODUCTION}

Inguinal hernia is one of the most common diseases in the society, and many repair techniques have been described throughout history. Advancements in perioperative anesthesia and operative technique have made this an outpatient ambulatory operation with low recurrence rates and morbidity. Given this success, quality of life and the avoidance of chronic pain have become the most important considerations in hernia repair (1). Today, tension-free repairs are accepted as the golden standard, and the problem of pain still remains in the post-operative period. Abdominal wall hernias are the displacement of intra-abdominal organs due to a gap between abdominal wall muscles and fascia layers, mesenteries or around the organs. Inguinal hernia is one of the most common abdominal wall hernias. Hernias seen in the inguinal and femoral regions are often categorized together and are called inguinal hernias. Approximately $75 \%$ of abdominal wall hernias occur in the groin. The lifetime risk of inguinal hernia is $27 \%$ in men and $3 \%$ in women (2). Of inguinal hernia repairs, $90 \%$ are performed in men and $10 \%$ in women. The incidence of inguinal hernias in males has a bimodal distribution, with peaks before the first year of age and after age 40 . Abramson demonstrated the age dependence of inguinal hernias in 1978. Ages 25 to 34 years had a lifetime prevalence rate of 15\%, whereas ages 75 years and over had a rate of $47 \%$. Approximately $70 \%$ of femoral hernia repairs are performed in women; however, inguinal hernias are five times 
more common than femoral hernias. The most common subtype of groin hernia in men and women is the indirect inguinal hernia (1). Chronic pain emerges as an important problem after hernia repair carried out with mesh. Although prolene meshes are most frequently used in hernia operations, progrip - self fixating mesh frequency has been increasing in recent years. Pain level and the time required to return to normal daily activities in a complete manner following the hernia surgery appear as the criteria used to measure the quality of life. In this study, it was aimed to compare the techniques applying prolene mesh-Surgipro $^{\mathrm{TM}}$ Covidien, A4B0694X, Mansfield/USA) -and progrip-self fixating- Parietene progrip ${ }^{\odot}$ (Covidien TEM1208GL-TEM1208GR, Berlin/Germany) mesh in terms of post-operative pain, limitation of movement and quality of life.

\section{MATERIAL and METHODS}

Fifty male patients who consulted the General Surgery Policlinic of Manisa Celal Bayar University Hospital with complaints of groin swelling and/or groin pain and were diagnosed with inguinal hernia between November 2014 and January 2016 were included in this prospective, randomized clinical study. These patients were applied with inguinal hernia repair with prolene mesh (Surgipro ${ }^{\text {TM }}$ Covidien, A4B0694X, Mansfield/USA) or self-fixating mesh (Progrip, Covidien, TEM1208GL-TEM1208GR, Berlin/ Germany). This scientific study began with the approval of the Manisa Celal Bayar University Local Ethics Committee (decision numbered 16/07/2014 / 20478486-271). Written consent of all the patients was received. The inguinal region shave of the patients was performed just before the operation. Antibiotic prophylaxis was applied to the patients by using cefazolin sodium $1 \mathrm{~g}$ intravenous (IV) (Cefozin, J01DB04, Bilim Ilaç San. ve Tic. AŞ, Beyoglu/ISTANBUL) half an hour before the operation. The study was carried out as a double blinded procedure. Pain inquiries of the patients were performed on the postoperative $1^{\text {st }}, 3^{\text {rd }}, 7^{\text {th }}$, $14^{\text {th }}$ and $60^{\text {th }}$ days by using the visual pain scale (VAS). On the postoperative $60^{\text {th }}$ day, Short Form-36 (SF-36) was evaluated in terms of quality of life. The inquiries were maintained as faceto-face during the hospitalization and by means of phones or policlinic controls during the post-discharge period.

Group 1 ( $n=25$ ) was applied with repair by using prolene graft.

Group $2(n=25)$ was applied with repair by using a progrip self-fixating graft.
Recurrent hernia, bilateral hernias, emergency cases and female patients were not included into the study. Post-operative analgesia was performed on the first day by using dexketoprofen trometamol bid (IV) and metamizole sodium qid (IV). From the first postoperative day, analgesia was achieved by using dexketoprofen trometamol bid [peroral (PO)]. It was projected to apply narcotic analgesic Tramadol HCL (drops) as an addition if analgesia could not be achieved with current treatments. Pain assessment was performed using visual pain scale (VAS). Statistical evaluation of this study was carried out with SPSS (Statistical Package for Social Sciences) program. The obtained data were entered into the database created in the SPSS 15 program and statistical analysis of the data was performed with the same program as well. Mean, standard deviation, median, minimum and maximum values of continuous variables and their subgroups and frequency numbers and percentages of class variables were presented. Independent group comparisons were made using the Independent Samples Test and the Mann-Whitney $U$ test. Paired Samples t-Test, and Wilcoxon Signed Ranks Test methods were used in paired groups. Analysis of variance (ANOVA) for repeated measurement was used in the comparison within groups, and intra-group comparison was performed using single-factor ANOVA. For all tests, type 1 error margin was selected as alpha: 0.05 and the difference between the groups was considered statistically significant if the value of $p$ was less than 0.05 .

\section{RESULTS}

The age range of 50 male patients participated in the study was 20-83 (mean 52.42); the age range of 25 participants in the prolene group was 23-83 (mean 54.72); the age range of 25 participants in the progrip group was 20-76 (mean 50.12) and there was no statistically significant difference ( $p>0.05$ ) (Table 1). There were right inguinal hernias in 26 (52\%) of the patients and left inguinal hernias in 24 (48\%) of the patients. Direct inguinal hernia was detected in 12 (24\%) patients, indirect inguinal hernia was detected in 29 (58\%) patients, and direct + indirect inguinal hernia were detected in the remaining 9 (18\%) patients (Table 2). On the $1^{\text {st }}$ postoperative day, mean pain was determined as 2.32 in the prolene group and as 1.52 in the progrip group $(p<0.05)$.

On the $3^{\text {rd }}$ postoperative day, mean pain score was determined as 1.32 in the prolene group; and as 0.72 in the progrip group

Table 1. Case numbers, age range and SF-36 score range

\begin{tabular}{|c|c|c|c|c|c|c|}
\hline & Number & Min & Max & Mean & SD & $p$ \\
\hline Age (prolen group) & 25 & 23 & 83 & 54.72 & 16.90 & \multirow[t]{2}{*}{0.15} \\
\hline Age (progrip group) & 25 & 20 & 76 & 50.12 & 17.52 & \\
\hline SF score (prolen group) & 25 & 86 & 146 & 116.24 & 16.09 & \multirow[t]{2}{*}{0.21} \\
\hline SF score (progrip group) & 25 & 85 & 144 & 124.20 & 17.07 & \\
\hline
\end{tabular}


Table 2. Type of hernia

\begin{tabular}{|l|c|c|}
\hline & Number & Percent \\
\hline Direct & 12 & 24 \\
\hline Indirect & 29 & 58 \\
\hline Direct + Indirect & 9 & 18 \\
\hline Total & 50 & 100 \\
\hline
\end{tabular}

Table 3. Postoperative pain and SF-36 scores according to graft types

\begin{tabular}{|c|c|c|c|c|c|c|c|}
\hline Graft type & & $\begin{array}{c}\text { Postop } 1^{\text {st }} \text { day } \\
\text { pain }\end{array}$ & $\begin{array}{c}\text { Postop } 3^{\text {rd }} \text { day } \\
\text { pain }\end{array}$ & $\begin{array}{c}\text { Postop } 7^{\text {th }} \text { day } \\
\text { pain }\end{array}$ & $\begin{array}{c}\text { Postop } 14^{\text {th }} \text { day } \\
\text { pain }\end{array}$ & $\begin{array}{c}\text { Postop } 60^{\text {th }} \text { day } \\
\text { pain }\end{array}$ & SF-36 score \\
\hline \multirow[t]{3}{*}{ Prolene } & Mean & 2.32 & 1.32 & 0.76 & 0.48 & 0.16 & 116.24 \\
\hline & $\mathrm{N}$ & 25 & 25 & 25 & 25 & 25 & 25 \\
\hline & SD & 1.31 & 0.62 & 0.43 & 0.50 & 0.37 & 16.09 \\
\hline \multirow[t]{3}{*}{ Progrip } & Mean & 1.52 & 0.72 & 0.24 & 0.16 & 0.08 & 124.20 \\
\hline & $\mathrm{N}$ & 25 & 25 & 25 & 25 & 25 & 25 \\
\hline & SD & 0.50 & 0.67 & 0.43 & 0.37 & 0.27 & 17.07 \\
\hline \multirow[t]{3}{*}{ Total } & Mean & 1.92 & 1.02 & 0.50 & 0.32 & 0.12 & 120.22 \\
\hline & $\mathrm{N}$ & 50 & 50 & 50 & 50 & 50 & 50 \\
\hline & SD & 1.06 & 0.71 & 0.50 & 0.47 & 0.32 & 16.90 \\
\hline \multicolumn{2}{|c|}{ Mann-Whitney U } & 168.00 & 174.50 & 162.50 & 225.00 & 287.50 & 194.50 \\
\hline \multicolumn{2}{|l|}{ Wilcoxon W } & 493.00 & 499.50 & 487.50 & 550.00 & 612.50 & 519.50 \\
\hline \multicolumn{2}{|l|}{ Z } & -3.06 & -2.98 & -3.36 & -2.13 & -1.03 & -2.29 \\
\hline \multicolumn{2}{|c|}{ Asymp. Sig. (2-tailed) } & 0.002 & 0.003 & 0.001 & 0.03 & 0.30 & 0.21 \\
\hline
\end{tabular}

$(p<0.05)$. On the $7^{\text {th }}$ postoperative day, mean pain score was determined as 0.76 in the prolene group; and as 0.24 in the progrip group ( $p<0.05$ ). On the $14^{\text {th }}$ postoperative day, mean pain was determined as 0.48 in the prolene group and as 0.16 in the progrip group $(p<0.05)$. On the $60^{\text {th }}$ postoperative day, mean pain was determined as 0.16 in the prolene group and as 0.08 in the progrip group $(p<0.05)$ (Table 3$)$. SF-36 score was determined 86 as the lowest, and although the progrip group seemed more advantageous in SF-36 scoring, a statistically significant difference was not determined. SF-36 score was determined 86 as the lowest and 146 the highest in the prolene group (mean=116.24) and 85 as the lowest and 144 as the highest in the progrip group $($ mean $=124.20)(p>0.05)($ Table 3$)$.

\section{DISCUSSION}

Inguinal hernia repair is still one of the most common practical applications in the world of daily surgery practice. Although it is seen in $75 \%$ of all hernias and $3.6 \%$ of the whole society, the best repair method is not certain yet. Hernia repair is expected to be simple and easy to apply. In the early period, patient comfort, a minimum cost of surgery, loss of workforce, length of stay in hospital and return to work and minimizing the recurrences are expected (2). Although the use of mesh in hernia repair reduces recurrence rates below 5\%, it also poses a major problem, such as chronic pain. Whether post-operative pain and returning to daily routine activities change according to the material and procedure applied in the surgery has also come to the fore and some studies have been carried out in this regard.

In a series of 60 cases published in 2013, Yilmaz et al. found that patients who were repaired with progrip self-fixating mesh had faster return to work and less postoperative pain compared to the patients repaired with prolene graft (3). The follow-up period of the study was four months and long-term outcomes are unknown. In our study the two-month period is based on and long-term results are also unknown. Observing long-term results may be important in determining the graft type to be used. In a series of 50 cases published in 2009, Kapischke et al. (2009) reported that the pain scores were lower in the progrip group than in the prolene group, but no statistically significant difference was found and longer follow-up was required as a result of the 6-month follow-up (4). In a complete series of 52 cases in 2008, 
Chastan et al. reported that none of the 52 patients followed up for 2 years with progrip had chronic pain or recurrence and that this could be the golden standard procedure for hernia repair (5). Since there is no control group in this study, it is not possible to assess whether the results are due to the experience of the surgical team or the method used. In this regard, the results obtained should be re-assessed by making a comparison with the control group.

In a similar study, Ozis et al. found that there was no significant difference between the two groups in terms of chronic pain in a series of 53 cases published in 2015 (6). In a series of 540 cases conducted between 2007 and 2012, Batabyal et al. evaluated the duration of operation during repairs made with two types of grafts and the duration of return to daily activities in the post-operative period. It was determined that the operation time in repairs applied with progrip self-fixating mesh was shorter compared to prolene repair and had more rapid return to daily activities than prolene graft (7). In this study, early period outcomes were based and no comment was made on chronic pain or long-term quality of life, therefore it is difficult to argue that there is a significant advantage in favour of progrip self-fixating with the available outcome.

Progrip or prolene repair was applied to 90 cases included in a prospective study conducted by Wang et al. between 2012 and 2013. It was determined that progrip graft was significantly superior in terms of post-operative pain and returning to work as a result of 6-month follow-up (8).

In our study, we determined that the pain measured by visual analogue scale (VAS) in the early postoperative period was significantly lower at a statistical level but there was no statistical significance in the second month and there was no statistically significant difference in SF-36 score at the end of the $2^{\text {nd }}$ month in daily routine activities in progrip self-fixating mesh group. In the followed-up patients, only one patient developed additional dose of analgesic need on the early periods such as $1^{\text {st }}$ and $3^{\text {rd }}$ post-operative days in the prolene group and contramal drops were applied to this patient, which may have affected the early VAS scores of this patient but did not affect the reliability of the data because it would not change the average of the entire group (8). In the meta-analysis of 1170 cases, Pandana et al. have compared progrip mesh and prolene mesh in terms of post-operative pain and found that there was no statistically significant difference (9). In a study of 1353 cases involving 6 randomized controlled studies published in 2014, Fang et al. determined that the operation time was shorter in the repairs applied with progrip. It was stated that there was no significant difference between postoperative pain and returning to daily activities during 12 months of follow-up (10). It was concluded that better organized studies with longer follow-up periods were required although one-year follow-up time was a good period.

\section{CONCLUSION}

Considering the literature related to this subject, there are some evidence that the repair applied with progrip self-fixating graft has more positive outcomes compared to the repairs applied with suture fixation; however, there are also some conflicting results. It is concluded that there is a need for longer follow-ups and larger series of cases in order to achieve a definite result.

Ethics Committee Approval: This scientific study began with the approval of the Manisa Celal Bayar University Local Ethics Committee (decision numbered 16/07/2014 / 20478486-271).

Informed Consent: Written consent of all the patients was received.

Peer-review: Externally peer-reviewed.

Author Contributions: Concept - A.S., A.K., T.C.; Design - A.S., A.K., S.T.Ş.; Supervision - A.S., Y.K., T.C.; Resource - A.K., T.C., Y.K.; Data Collection and/ or Processing - S.T.S., T.C., A.S.; Analysis and/or Interpretation - A.S., A.K., T.C.; Writing Manuscript - A.K., S.T.Ş., A.S.; Critical Reviews - S.T.Ş., T.C., Y.K.

Conflict of Interest: There is no conflict of interest in this study.

Financial Disclosure: This study has no financial support.

\section{REFERENCES}

1. Schwartz. Principles of Surgery. 10 $0^{\text {th }}$ ed. McGraw Hill Co, 2014; Chapter 37:1495-516. [CrossRef]

2. Banks SB, Cotlar AM. Classic groin hernia repair. Curr Surg 2005;62(2):249-52. [CrossRef]

3. Yilmaz A, Yener O, Kaynak B, Yigitbasi R, Demir M, Burcu B, et al. Selfgripping Covidien ProGrip mesh versus polypropylene mesh in open inguinal hernia repair: multicenter short term results. Prague Med Rep 2013;114(4):231-8. [CrossRef]

4. Kapischke M, Schulze $H$, Caliebe A. Self-fixating mesh for the Lichtenstein procedure-aprestudy. Langenbecks Arc Surg 2010;395:31722. [CrossRef]

5. Chastan P. Tension-free open hernia repair using an innovative selfgripping semi-resorbable mesh. Hernia 2009;13:137-42. [CrossRef]

6. Öziş SE, Ünal Çevik I, Uslu HY, Özdemir S, Gülpinar K, Aydin HT. The long-term changes in pain-related symptomatology of inguinal hernia following 2 different herniorrhaphy techniques. Turk J Med Sci 2015;45(1):202-7. [CrossRef]

7. Batabyal P, Haddad RL, Samra JS, Wickins S, Sweeney E, Hugh TJ. Inguinal hernia repair with Parietex ProGrip mesh causes minimal discomfort and allows early return to normal activities. Am J Surg 2016;211(1):24-30. [CrossRef]

8. Wang $Y$, Zhang $X$. Short-term results of open inguinal hernia repair with self-gripping Parietex ProGrip mesh in China: a retrospective study of 90 cases. Asian J Surg 2016;39(4):218-24. [CrossRef]

9. Pandanaboyana S, Mittapalli D, Rao A, Prasad R, Ahmad N. Metaanalysis of self-gripping mesh (Progrip) versus sutured mesh in open inguinal hernia repair. Surgeon 2014;12(2):87-93. [CrossRef]

10. Fang Z, Zhou J, Ren F, Liu D. Self-gripping mesh versus sutured mesh in open inguinal hernia repair: system review and meta-analysis. Am J Surg 2014;207(5):773-81. [CrossRef] 


\title{
ORIJINAL ÇALIŞMA-ÖZET
}

Turk J Surg 2020; 36 (1): 48-52

\section{İnguinal herni onarımında prolen ve progrip yamalarının postoperatif ağrı, hareket kısıtıılığı ve yaşam kalitesi açısından karşılaştırılması}

\author{
Ahmet Kaya ${ }^{1}$, Semra Tutcu Şahin², Yavuz Kaya², Teoman Coşkun² ${ }^{2}$ Aslan Sakarya² \\ ${ }^{1}$ Sakarya Üniversitesi Tıp Fakültesi, Cerrahi Onkoloji Bilim Dalı, Sakarya, Türkiye \\ ${ }^{2}$ Celal Bayar Üniversitesi Tıp Fakültesi, Genel Cerrahi Anabilim Dalı, Manisa, Türkiye
}

\section{ÖZET}

Giriş ve Amaç: Bu çalışmada amaç, ameliyat sonrası ağıı, hareket kısıtlaması ve yaşam kalitesi açısından prolen mesh ve progrip-self fiksasyon mesh uygulama tekniklerini karşılaştırmaktır.

Gereç ve Yöntem: Çalışma Kasım 2014-Ocak 2016 tarihleri arasında Manisa Celal Bayar Üniversitesi Hastanesinde yapıldı. Çalışmaya 18 yaşından büyük 50 erkek hasta alındı ve çalışma çift-kör prosedürle gerçekleştirildi. Yirmi beş hasta progrip yama yöntemiyle, 25 hasta ise prolen greftleri kullanılarak dikiş fiksasyon yöntemiyle tedavi edildi ve hastaların ağıı takibi yüz yüze ya da telefon görüşmeleriyle yapıldı. VAS (Görsel Analog Skala) ve günlük rutin aktivitelere dönüş, SF-36 (Kısa Form-36) yaşam kalitesi ölçeği ile değerlendirildi. Tekrarlayan fıtıklar ve acil durumlar çalışma kapsamına alınmadı. Veriler, SPSS paket programı kullanılarak analiz edildi.

Bulgular: Yapılan değerlendirmeler sonucunda, ameliyat sonrası erken dönemde progrip kendinden fikse mesh kullanan hastalarda ağrı skorlarının daha düşük ve istatistiksel olarak anlamlı olduğu bulunmuştur. Uzun dönemde her iki yöntem de ağrı ve yaşam kalitesi açısından istatistiksel olarak benzer sonuçlar vermiştir.

Sonuç: Bu konuyla ilgili literatür göz önüne alındığında, progrip kendinden fiksasyon grefti ile yapılan onarımın, dikiş fiksasyonu ile yapılan onarımlara kıyasla daha olumlu sonuçlara sahip olduğuna dair bazı kanıtlar vardır, ancak bazı çelişkili sonuçlar da vardır. Kesin bir sonuç elde etmek için daha uzun takiplere ve daha geniş olgu serilerine ihtiyaç olduğu sonucuna varılmıştır.

Anahtar Kelimeler: İnguinal herni, ağrı, progrip yama, prolen yama, yaşam kalitesi

Doi: $10.5578 /$ turkjsurg.4451 